Article

\title{
Agricultural Education in Today's School System: An Evaluation of Agricultural and Related Science Courses among High Schools in Alabama, USA
}

\author{
Rosny Jean * and Colmore Christian \\ Biological and Environmental Sciences Department, Alabama A\&M University, Normal, AL 35762, USA; \\ colmore.christian@aamu.edu \\ * Correspondence: rjean2@bulldogs.aamu.edu; Tel.: +1-256-372-4571
}

Received: 24 August 2018; Accepted: 25 October 2018; Published: 1 November 2018

\begin{abstract}
Previous studies on global food security have indicated that in order to sustain the global population by the year 2050, a significant increase in food production will be needed. Consequently, it is crucial that today's students are educated to realize this increasing food demand. One of the problems is that currently too few students seem to be interested in pursuing studies in the fields of agriculture and related sciences. By exploring three research questions, this study assesses the extent to which high school students in each of the 67 counties in the U.S. state of Alabama are being exposed to agricultural-related science courses. For the purposes of this assessment, the high schools were grouped by zones-Northern, Central, Southern and the Black Belt. Relevant high school data, including courses offered, were compiled from Alabama's Department of Education 2017 directory. Microsoft Excel and SPSS software were used to analyze the data. The findings of this study demonstrated that there are spatial differences in agriculture-related courses offered in high schools in Alabama's Northern, Central and Southern regions. Future research should further investigate what percentage of high school students actually choose agriculture or related disciplines as their professional career paths after graduating from high school.
\end{abstract}

Keywords: United State of America Education; Alabama; high School; agricultural sciences; students

\section{Introduction}

Attracting the next generation of farmers and agricultural professionals in the United States remains a great challenge in the agricultural sector. It is reported that, over the years, fewer and fewer students are attracted to agriculture and agriculture-related courses (Zahn 2012). According to the U.S. Department of Agriculture (USDA), which is entrusted with the task of improving economic opportunities in the rural areas of the U.S., over 57,000 jobs are created in agriculture, environment and renewable natural resources every year in the U.S. However, only 35,400 new graduates are available to fill these positions, leaving a huge shortfall of over 22,500 graduates annually (Purdue 2015).

It has been widely recognized by federal and state governments, their education departments, and many national-level bodies that considerable efforts are needed to change the perceptions of high school students towards making agriculture their career choice. In the past, the U.S. school system provided agricultural education through vocational training mainly for students who wanted to become agricultural producers or intended to pursue their career in the off-farm agricultural industry after high school graduation. This approach was part of a broad strategy to address the shortage of human capacity in different industries (Alabama Department of Education 2008).

This strategy is often viewed as an element of national policy to boost education development on specific national needs, such as Science, Technology, Engineering, and Mathematics (STEM) 
and agriculture-related fields in the different regions and at the national level (Ilnicki 2009). Such government efforts are aimed at supporting regional and national social-economic development and improving education in general (Aitbayevaa et al. 2016). Under this approach, central and local governments often use grants and other instruments, thereby contributing to the concentration of higher educational institutes in certain cities or territories (Veeravalli 2010). This generally creates spatial patterns in the U.S. education system with centers at different levels and with different subjects dominant in different regions where this policy is implemented.

Alabama, like many other states, has adopted such national policies in its educational system to fill the deficit of the next generation of professionals in the agricultural industry. Alabama's school system seeks to expose students as early as middle and high school levels to agriculture-related courses as a way of changing students' perceptions of agriculture. As discussed in Section 2, Alabama has established a number of courses designed to equip students with the knowledge and skills needed for various agriculture-related careers.

\section{Research Questions}

This study sought to analyze the distribution of high schools in Alabama that introduce students to agriculture-related fields. In this regard, three research questions have been explored:

1. Does the average number of high schools which offer courses in agriculture-related fields differ across Alabama's regions (Central, North, and South as well the Black Belt)?

2. Does the average number of high schools with courses in agriculture-related fields in Alabama's Black Belt differ from the rest of the state?

3. Does the average number of agriculture-related courses in high schools vary across Alabama's regions?

\section{Literature Review}

Agricultural education in Alabama, as across the country, provides a wide range of experiences to students both in and outside of the classroom. Some of these experiences are promoted and accomplished through organizations such as 4- $\mathrm{H}$, a non-formal arm of the U.S. agricultural education model for youth development, and the Future Farmers of America (FFA), a leadership development organization which complements the formal or in-school part of the agricultural education system (Agclassroom.org 2017).

However, Alabama's education system has developed some unique ways to promote agriculture among high school students. High schools in Alabama have the option of offering any one or combination of five agriculture-related course concentrations, namely: Agribusiness Systems; Plant Systems; Animal Systems; Environmental and Natural Resources Systems; and Power, Structural, and Technical Systems. The Agricultural Science course is a foundation course that is offered to all ninth through twelfth-grade students. This Agricultural Science course provides students with essential knowledge, along with the training needed to work in this field. On-site visits and work shadowing are the techniques used to impart deeper understanding in these fields of agriculture (Alabama Department of Education 2008).

High school freshman students in Alabama are offered an Agricultural Science Exploration course. This course helps students gain knowledge and skills related to the agriculture industry. Some of the topics discussed in this course are soil science, conservation, plant science, animal science, agricultural-marketing, aquaculture, woodworking and power mechanics. Teachers go beyond the curriculum to include specific and relevant community interests. Courses are designed to encourage critical thinking, leadership skills, integration of technology, and use of the scientific method.

Alabama's Department of Agriculture works in tandem with the Department of Education to achieve the goal of developing a quality and motivated workforce to enhance the agricultural economy of the state. While careers in agriculture, forestry, and agriculture business in the state are on the 
rise exponentially (Alabama Department of Education 2008), industries and businesses are facing critical shortages of manpower. Continued shortages of manpower may affect agriculture and related businesses significantly. In these circumstances, the Department of Education has taken several steps to address the problem. To date, the Department has:

1. Established internship programs in collaboration with the private sector for high school students so that students' interest in agriculture can be enhanced.

2. Opened multipurpose centers with the aim of enhancing youth involvement in agribusiness and forestry.

3. Started workforce development programs that can increase career awareness of agriculture, forestry and agribusiness among public school students.

4. Enhanced the number of agriculture-science programs by $15 \%$.

5. Organized career awareness programs to ignite passion among youth for agriculture, agribusiness, and forestry.

Such initiatives are widely attractive and welcomed among students and stakeholders. A Shelby County young farmer stated that: "Teaching students about agriculture at an early age plants seeds of hope for growing a stronger agricultural future in Alabama" (Moore 2016). The hands-on education, which is provided to students in preparatory classes in Shelby County, Alabama, involves shoveling and tilling fertilizers into the soil and planting trees, bringing students closer to agriculture in the days ahead. In other words, the Farmers' Federation can do a great job in building awareness about agriculture among students at an early age (Moore 2016).

\section{Conceptual Framework}

Researchers have indicated that the education system should design courses that support the main drivers of the local economic activities (Wang 2010). Moreover, the spatial distribution of educational institutions is examined in relation to the possible role of education as a driver for economic growth (Wang 2010).

Such an approach makes it possible to determine whether macro-areas exist where the teaching of specific subjects or scientific fields is dominant in comparison with other regions. Thus, four regions of Alabama-North, Central, South, and the Black Belt (Figures 1 and 2)-were investigated as possible different 'macro academic' areas in reference to agriculture-related courses. In addition, the Black Belt area is considered as being possibly distinct from the rest of Alabama because of the area's rich, black soils.

The teaching of specific subjects also has an unequal spatial distribution at the municipal, regional, national and global levels. Higher education institutions with courses in certain subjects are concentrated in specific centers or regions, which can be caused by the structure of a regional economy or due to historical reasons (Frenkel and Leck 2017). Each such center has its own area of influence, named by some researchers an "academic region" (Ilnicki 2009). The influence area of the "academic region" includes an administrative unit (for example, a county) where the educational institute is located and can also include the neighboring administrative units (Ilnicki 2009). 


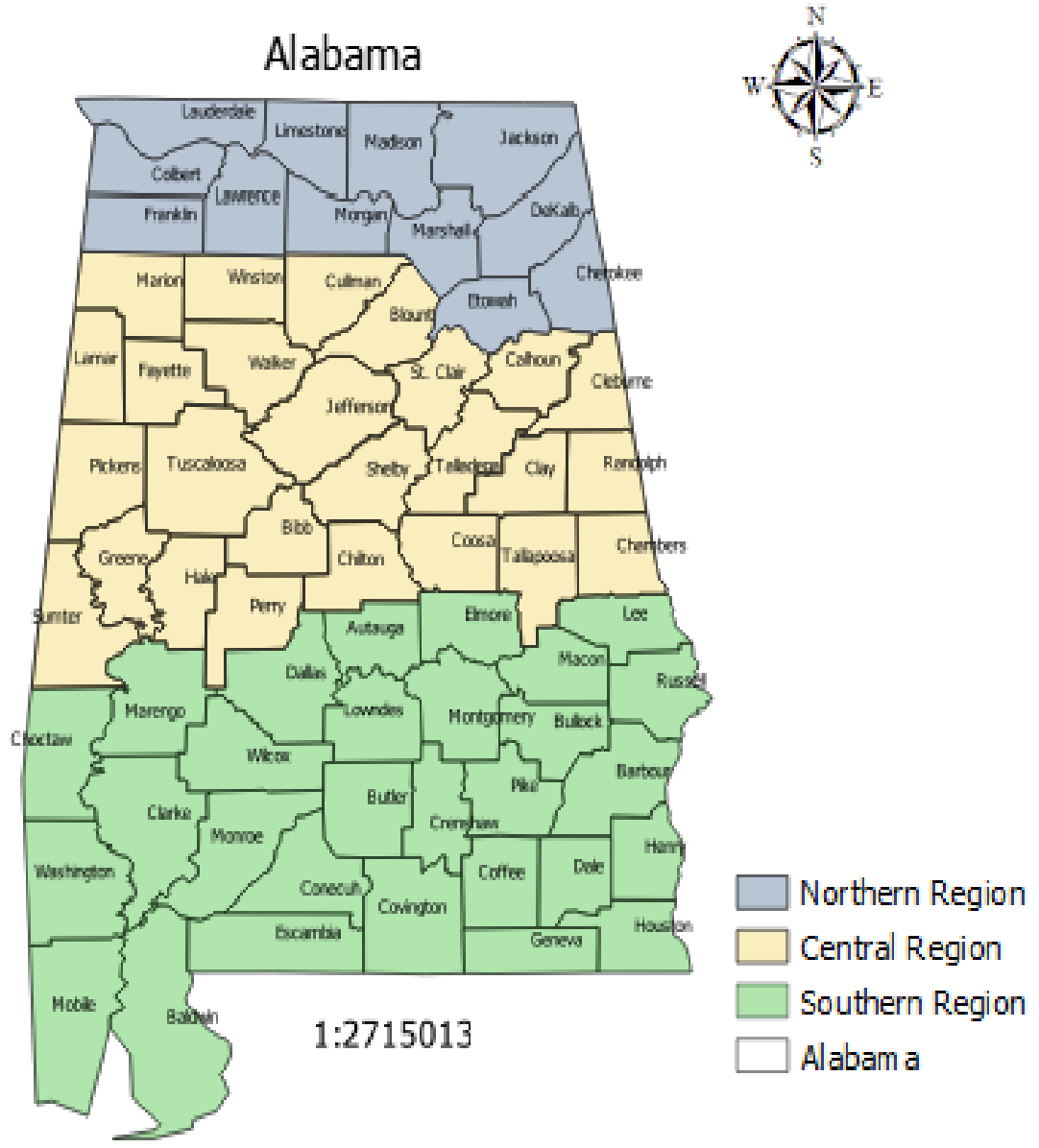

Figure 1. Map of Alabama demonstrating the three primary different regions.

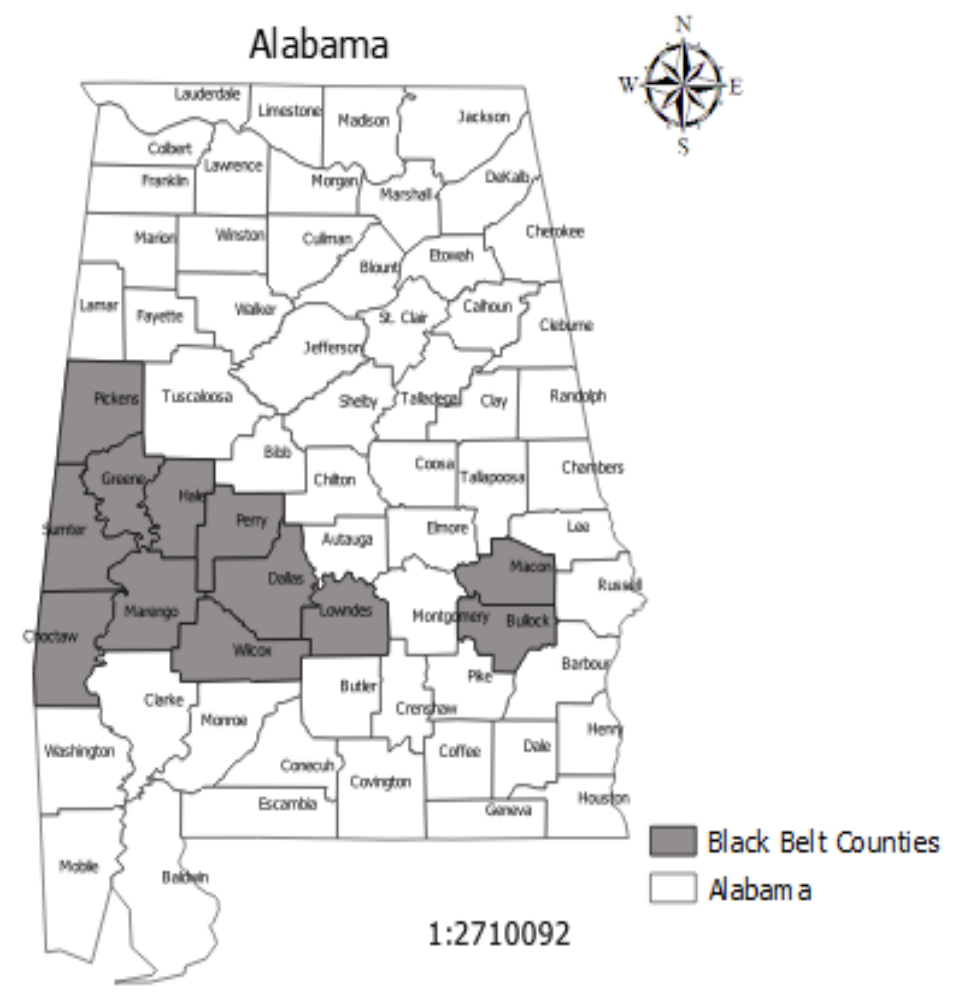

Figure 2. Map indicating the twelve counties which make-up Alabama's Black Belt. 


\section{Methodology}

\section{Data Collection and Analysis}

Data concerning high schools that offer agriculture-related courses were compiled from two sources for each of Alabama's 67 counties using the Alabama's Department of Education directory (Alabama State Department of Education 2017) and personal communication from a senior official in the Department of Education (Jacob Davis, per, comm.). SPSS version 25 was used for data analysis, and the chi-squared test was used for pairwise comparisons: Central-North, Central-South, and North-South, as well as the Black Belt region and the rest of the state. For this, the corresponding contingency tables were generated. In cases where more than $20 \%$ of the cells had expected frequencies of less than 5, Fisher's exact test was used as the more appropriate method of comparison (Kim 2017).

The following twelve counties were identified and included in Alabama's Black Belt area: Bullock, Choctaw, Dallas, Greene, Hale, Lowndes, Macon, Marengo, Pickens, Perry, Sumter, and Wilcox.

Corresponding dummy variables were created with value " 1 " for the Black Belt counties and value " 0 " for all other counties. Then, the chi-squared test was used to check the difference in the proportions of the schools where agriculture-related courses are offered.

Considering the presence of many 'zeroes' in the data, the Mann-Whitney test was used for a comparison of the average number of high schools with agriculture-related courses per 10,000 persons across counties, then a probability of $p<=0.05$ was chosen as the significance level.

The shape files from the U.S Geological Survey (USGS) National Boundary Dataset (NBD) (U.S. Geological Survey, National Geospatial Technical Operations Center 2018) were used for developing maps. The spatial distribution of agriculture-related courses was illustrated using Esri ArcGIS software 10.4.1 version.

Hence, in accordance with the National Center for Health Statistics' (Ingram and Franco 2012) population scale, cities with a population of 10,000 or under are categorized as small, and cities with a population between 10,000 and 50,000 are classified as medium in size. Thereby, the cities within the Alabama counties that were used in this study were classified as small- to midum-sized (i.e., 10,000). Therefore, the denominator 10,000 scale was used to make the data more suitable for analysis.

\section{Results and Discussion}

In general, the 310 Alabama High Schools reported 366 examples of introducing their students to agriculture-related fields. Two high schools $(0.6 \%)$ reported courses related to three different concentrations within the agricultural fields; 52 high schools $(16.8 \%)$ reported courses related to two different agricultural fields, and the remaining 256 high schools (82.6\%) indicated one agricultural field. General agricultural science was the course reported most often (118 schools), while no school reported Floral design (Figure 3). Therefore, Floral Design was excluded from further analysis.

Figure 4 shows the spatial distribution of high schools with courses in agriculture-related fields across Alabama's counties. A visual inspection of this figure indicates that high schools with courses in agriculture-related fields are more concentrated in the North and South of Alabama. This may be due to strategies that are in place to prepare students for the specific regional agricultural market. According to the Alabama Agricultural Statistics report, agriculture-related industries, such as animal production, are located in the northern part of the state (USDA NASS 2017). 


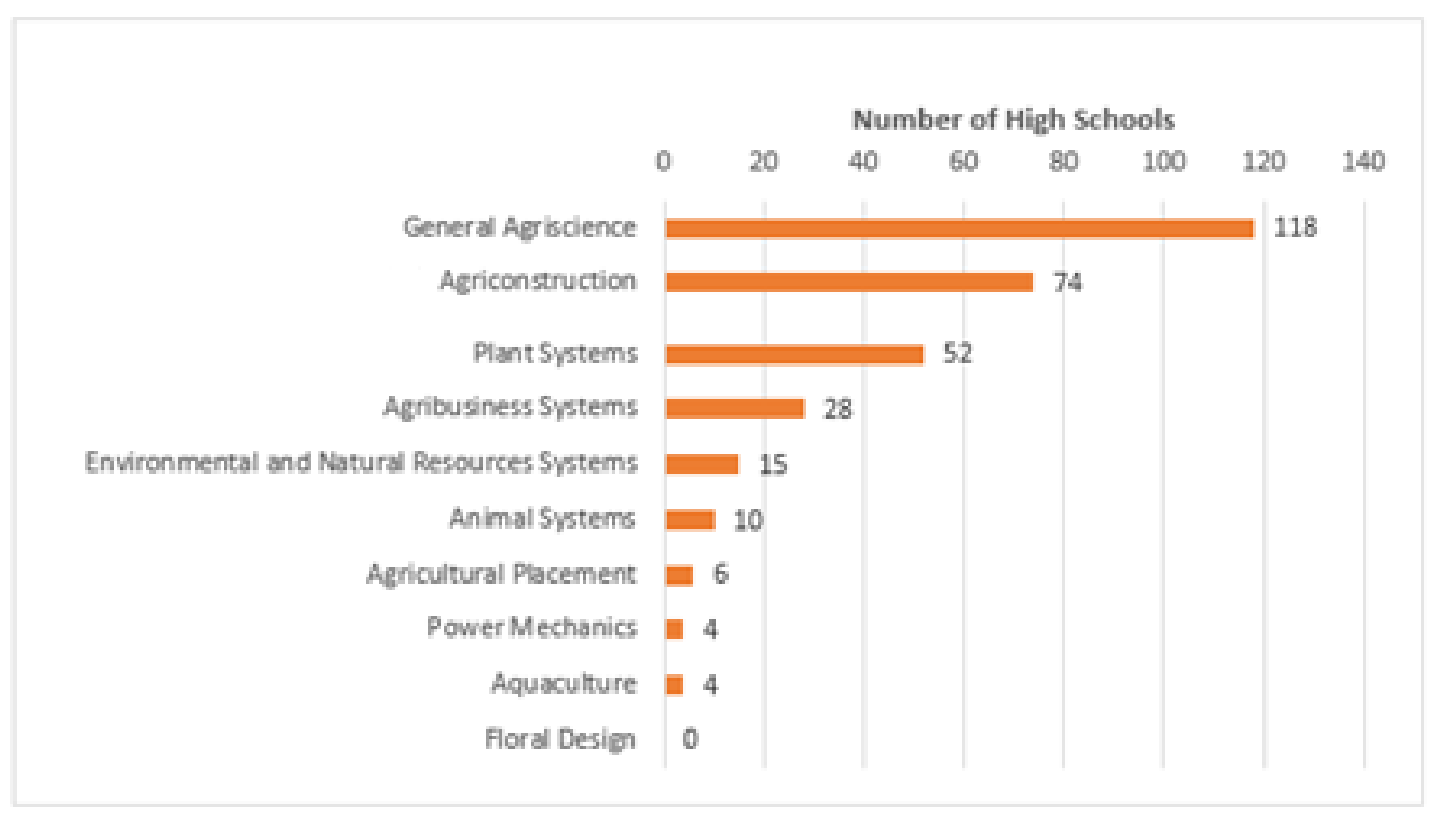

Figure 3. The frequencies of agriculture-related courses in Alabama's high schools.

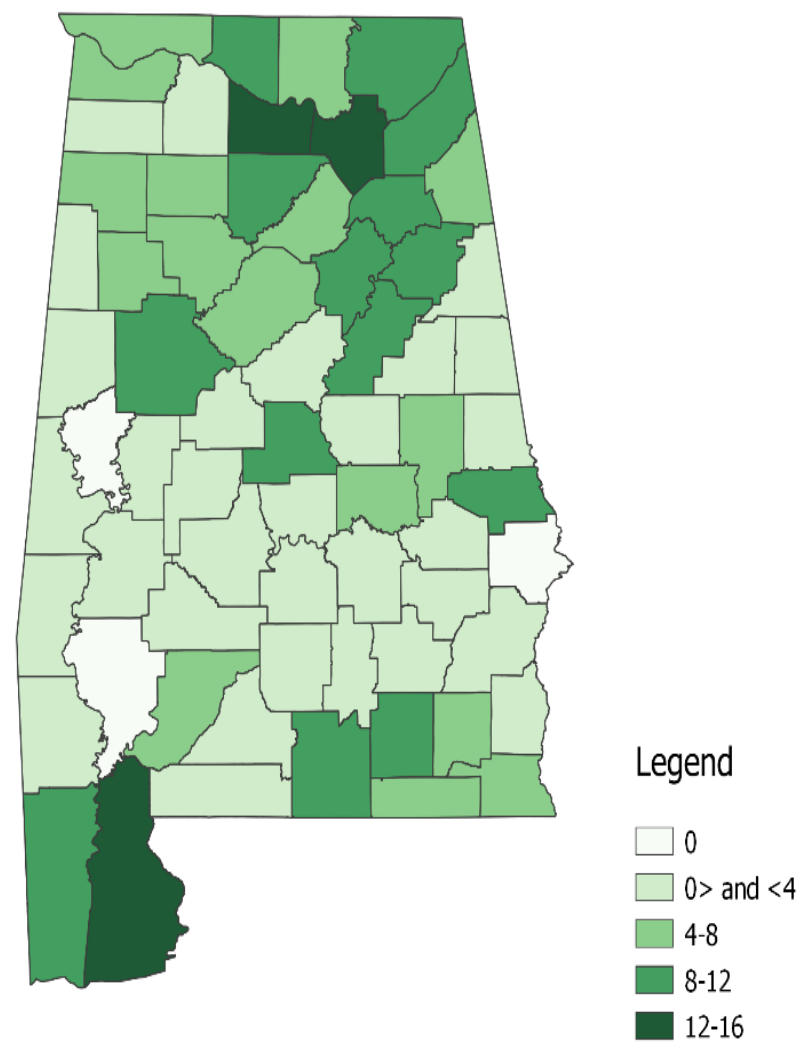

Figure 4. The spatial distribution of high schools with agriculture-related courses across Alabama's counties.

The presentation and discussion of the three research questions explored in this analysis are reflected in the following sub-section. 
4.1. Spatial Differences in Agriculture-Related Courses Offered in Alabama's Black Belt Counties and the Other Alabama's Counties

Table 1 displays the results of the comparison of the average number of high schools with an agriculture-related course in Alabama's Black Belt area and the rest of the State.

Table 1. Agriculture-related courses in Alabama's Black Belt area, compared with the rest of the State.

\begin{tabular}{|c|c|c|c|c|}
\hline \multirow[t]{2}{*}{ Agriculture-Related Fields } & \multicolumn{2}{|c|}{$\begin{array}{l}\text { The Average Number of High Schools with } \\
\text { Agriculture-Related Courses by County, per } \\
10,000 \text { Inhabitants }\end{array}$} & \multirow[t]{2}{*}{$\begin{array}{l}\text { Mann-Whitney } \\
\text { Test Z-Statistics }\end{array}$} & \multirow[t]{2}{*}{$\begin{array}{l}p \text {-Value } \\
\text { (2-Tailed) }\end{array}$} \\
\hline & Black Belt Area & The Rest of Alabama & & \\
\hline $\begin{array}{l}\text { Total high schools with } \\
\text { agriculture-related courses per } \\
10,000 \text { persons }\end{array}$ & 1.653 & 1.253 & -0.948 & 0.343 \\
\hline Agricultural Placement & 0.145 & 0.021 & -1.435 & 0.151 \\
\hline General Agricultural Science & 0.130 & 0.442 & -2.947 & 0.003 \\
\hline Agriculture Construction & 0.608 & 0.273 & -1.851 & 0.064 \\
\hline Power Mechanics & 0.000 & 0.005 & -0.821 & 0.411 \\
\hline Animal Systems & 0.000 & 0.024 & -1.294 & 0.196 \\
\hline Plant Systems & 0.159 & 0.147 & -1.447 & 0.148 \\
\hline Agriculture Business Systems & 0.078 & 0.088 & -1.012 & 0.311 \\
\hline $\begin{array}{l}\text { Environmental and Natural } \\
\text { Resource Systems }\end{array}$ & 0.041 & 0.042 & -0.810 & 0.420 \\
\hline Aquaculture & 0.000 & 0.007 & -0.956 & 0.339 \\
\hline
\end{tabular}

Table 1 indicates only one significant difference in agriculture-related courses between Alabama's Black Belt and the rest of the state: the average number of high schools offering the General Agricultural Science course in the Black Belt counties (0.130) is statiscally significantly lower than other counties (0.442). All other differences are statistically insignificant.

\subsection{Spatial Aspects of the Prevalence of Agriculture-Related Courses in Alabama's High Schools}

Table 2 reflects the results of the comparison across Alabama's regions of the prevalence of courses related to agricultural fields in high schools (the total number of high schools is in parentheses).

Only a few significant differences in the prevalence of courses related to agricultural fields in high schools across Alabama's regions were evident. Courses related to Agribusiness Systems were offered more often in high schools in the North (20 schools, or $15.4 \%$ of all high schools), compared with the Central region ( 3 schools, $3.20 \%$ ) and the South (5 schools, $5.90 \%$ ).

Courses related to Agricultural Science were also studied more often in the Northern high schools (31 schools, 23.80\%) compared with the South (10 schools, 11.80\%), while the difference between the Northern and Central regions was insignificant at the 0.05 level.

Courses related to Plant Systems were studied in the Northern high schools (16 schools, $12.30 \%$ ) less often compared to the South (20 schools, $23.50 \%$ ).

Courses within the Environmental and Natural Resources Systems field were studied in high schools in the Central region ( 8 schools, $8.40 \%$ ) more often than the South region ( 1 school, $1.2 \%$ ).

In general, the results show that the prevalence of the majority of the courses does not differ across Alabama's regions (7 related to agricultural fields out of 11 investigated, including "Floral design").

Table 3 displays the prevalence of Agricultural Science courses in high schools in Alabama's Black Belt area in comparison with the rest of Alabama. The total number of high schools is in parentheses.

Table 3 shows two significant differences between the Black Belt and the rest of Alabama. Courses related to General Agricultural Science were studied in high schools in the Black Belt area (2 schools, $9.50 \%$ ) less often compared to the rest of Alabama (116 schools, $40.10 \%)$. In contrast, courses related to agricultural construction were studied in high schools in Alabama's Black Belt area more often (10 schools, $47.60 \%$ ) compared to the rest of Alabama (64 schools, $24.10 \%$ ). 
Table 2. The Prevalence of courses related to agricultural fields in high schools across Alabama's regions.

\begin{tabular}{|c|c|c|c|c|c|c|}
\hline \multirow[t]{2}{*}{ Courses } & \multicolumn{2}{|c|}{$\begin{array}{c}\text { The Number of High Schools } \\
\text { with Agriculture-Related } \\
\text { Courses }\end{array}$} & \multicolumn{2}{|c|}{$\begin{array}{l}\text { The Percentage of High } \\
\text { Schools with } \\
\text { Agriculture-Related Courses }\end{array}$} & \multirow[t]{2}{*}{$\chi^{2}$ Statistics } & \multirow[t]{2}{*}{$\begin{array}{c}p \text {-Value } \\
\text { (2-Tailed) }\end{array}$} \\
\hline & North (130) & South (85) & North (130) & South (85) & & \\
\hline $\begin{array}{l}\text { High schools offering } \\
\text { Agricultural Science }\end{array}$ & 31 & 10 & $23.80 \%$ & $11.80 \%$ & 4.861 & 0.027 \\
\hline Agricultural Placement & 0 & 3 & $0 \%$ & $3.50 \%$ & 4.653 & $0.060 \mathrm{a}$ \\
\hline General Agricultural Science & 53 & 30 & $40.80 \%$ & $35.30 \%$ & 0.65 & 0.42 \\
\hline Agriculture Construction & 26 & 22 & $20 \%$ & $25.90 \%$ & 1.026 & 0.311 \\
\hline Power Mechanics & 1 & 3 & $0.80 \%$ & $3.50 \%$ & 2.145 & $0.303 a$ \\
\hline Animal Systems & 1 & 4 & $0.80 \%$ & $4.70 \%$ & 3.506 & $0.081 \mathrm{a}$ \\
\hline Plant Systems & 16 & 20 & $12.30 \%$ & $23.50 \%$ & 4.643 & 0.031 \\
\hline Agriculture Business Systems & 20 & 5 & $15.40 \%$ & $5.90 \%$ & 4.516 & 0.034 \\
\hline $\begin{array}{l}\text { Environmental and Natural } \\
\text { Resources }\end{array}$ & 6 & 1 & $4.60 \%$ & $1.20 \%$ & 1.93 & $0.249 a$ \\
\hline Aquaculture & $\begin{array}{c}\mathbf{0} \\
\text { Central (95) }\end{array}$ & $\begin{array}{c}2 \\
\text { South (85) }\end{array}$ & $\begin{array}{c}\mathbf{0 . 0 0 \%} \\
\text { Central (95) }\end{array}$ & $\begin{array}{c}2.40 \% \\
\text { South (85) }\end{array}$ & 3.088 & $0.155 a$ \\
\hline $\begin{array}{l}\text { High schools offering } \\
\text { Agricultural Science }\end{array}$ & 14 & 10 & $14.70 \%$ & $11.80 \%$ & 0.343 & 0.558 \\
\hline Agricultural Placement & 3 & 3 & $3.20 \%$ & $3.50 \%$ & 0.019 & $>0.999 a$ \\
\hline General Agricultural Science & 35 & 30 & $36.80 \%$ & $35.30 \%$ & 0.047 & 0.829 \\
\hline Agriculture Construction & 26 & 22 & $27.40 \%$ & $25.90 \%$ & 0.051 & 0.822 \\
\hline Power Mechanics & 0 & 3 & $0.00 \%$ & $3.50 \%$ & 3.41 & $0.103 a$ \\
\hline Animal Systems & 5 & 4 & $5.30 \%$ & $4.70 \%$ & 0.029 & $>0.999 a$ \\
\hline Plant Systems & 16 & 20 & $16.80 \%$ & $23.50 \%$ & 1.254 & 0.263 \\
\hline Agriculture Business Systems & 3 & 5 & $3.20 \%$ & $5.90 \%$ & 0.784 & $0.479 a$ \\
\hline $\begin{array}{l}\text { Environmental and Natural } \\
\text { Resource Systems }\end{array}$ & 8 & 1 & $8.40 \%$ & $1.20 \%$ & 4.957 & $0.037 \mathrm{a}$ \\
\hline Aquaculture & 2 & 2 & $2.10 \%$ & $2.40 \%$ & 0.013 & $>0.999 a$ \\
\hline
\end{tabular}

a- $p$-value of Fisher's Exact Test is reported because more than $20 \%$ of the cells have expected frequencies of less than 5 .

Table 3. The prevalence of courses related to agriculture in high schools in Alabama's Black Belt area in comparison with the rest of the State.

\begin{tabular}{|c|c|c|c|c|c|c|}
\hline \multirow[t]{2}{*}{ Courses } & \multicolumn{2}{|c|}{$\begin{array}{c}\text { The Number of High Schools with } \\
\text { Agriculture-Related Courses }\end{array}$} & \multicolumn{2}{|c|}{$\begin{array}{c}\text { The Percentage of High Schools } \\
\text { with Agriculture-Related } \\
\text { Courses }\end{array}$} & \multirow[t]{2}{*}{$\chi^{2}$ Statistics } & \multirow[t]{2}{*}{$\begin{array}{l}p \text {-Value } \\
\text { (2 Tailed) }\end{array}$} \\
\hline & Black Belt (21) & $\begin{array}{c}\text { The rest of } \\
\text { Alabama (289) }\end{array}$ & Black Belt (21) & $\begin{array}{c}\text { The rest of } \\
\text { Alabama (289) }\end{array}$ & & \\
\hline $\begin{array}{l}\text { High schools offering } \\
\text { Agricultural Science }\end{array}$ & 7 & 48 & $33.30 \%$ & $16.60 \%$ & 3.752 & $0.072 \mathrm{a}$ \\
\hline $\begin{array}{l}\text { Agricultural } \\
\text { placement }\end{array}$ & 2 & 4 & $9.50 \%$ & $1.40 \%$ & 6.834 & $0.056 a$ \\
\hline $\begin{array}{l}\text { General Agricultural } \\
\text { Science }\end{array}$ & 2 & 116 & $9.50 \%$ & $40.10 \%$ & 7.783 & 0.005 \\
\hline $\begin{array}{l}\text { Agriculture } \\
\text { Construction }\end{array}$ & 10 & 64 & $47.60 \%$ & $22.10 \%$ & 6.991 & 0.008 \\
\hline Power Mechanics & 4 & 0 & $0 \%$ & $1.40 \%$ & 0.294 & $>0.999 a$ \\
\hline Animal Systems & 0 & 10 & $0.00 \%$ & $10.00 \%$ & 0.751 & $>0.999 a$ \\
\hline Plant Systems & 25 & 50 & $9.50 \%$ & $17.30 \%$ & 0.848 & $0.547 a$ \\
\hline $\begin{array}{l}\text { Agriculture Business } \\
\text { Systems }\end{array}$ & 1 & 27 & $4.80 \%$ & $9.30 \%$ & 0.50 & $0.706 a$ \\
\hline $\begin{array}{l}\text { Environmental and } \\
\text { Natural Resource } \\
\text { Systems }\end{array}$ & 1 & 14 & $4.80 \%$ & $4.80 \%$ & 0.00 & $>0.999 a$ \\
\hline Aquaculture & 0 & 4 & $0.00 \%$ & $1.40 \%$ & 0.294 & $>0.999 a$ \\
\hline
\end{tabular}

a- $p$-value of Fisher's Exact Test is reported because more than $20 \%$ of the cells have expected frequencies of less than 5 .

Calculated values for skewness (1.965) and kurtosis (2.747) indicate significant departures from the mean number of agriculture-related courses studied in Alabama's high schools. However, the acceptable range is \pm 2 for skewness and \pm 4 for 'excess' kurtosis, as calculated by SPSS (Kim 2013). Thus, the data distribution departure from a normal distribution is not substantial.

There were no significant differences in the mean number of agriculture-related courses studied in Alabama's High Schools (Table 4). 
Table 4. A comparison of the mean number of agriculture-related courses studied in Alabama's High schools across the three regions.

\begin{tabular}{cccccc}
\hline & \multicolumn{2}{c}{ Means } & $\begin{array}{c}\text { Mean } \\
\text { Difference }\end{array}$ & t-Statistics & $\begin{array}{c}p \text {-Value } \\
\text { (2 Tailed) }\end{array}$ \\
\hline North-Central & 1.185 (North) & 1.179 (Central) & 0.0057 & 0.105 & 0.916 \\
North-South & 1.185 (North) & 1.177 (South) & 0.0081 & 0.142 & 0.887 \\
Central-South & 1.179 (Central) & 1.177 (South) & 0.0025 & 0.042 & 0.967 \\
\hline
\end{tabular}

\subsection{Spatial Differences in Agriculture-Related Courses across Alabama's Northern, Central, and} Southern Regions

The number of high schools with an agriculture-related course was calculated for each county in Alabama. Then, the recorded values were normalized for 10,000 inhabitants, based on the average population of the relevant counties. The average value was calculated for the Northern, Central, and Southern regions of the State. Furthermore, these values were compared using the Mann-Whitney test. The results are reported in Table 5. Only three significant differences were found.

Table 5. A comparison of the average number of high schools with agriculture-related field learning (per 10,000 inhabitants) in Alabama's northern, central, and southern regions.

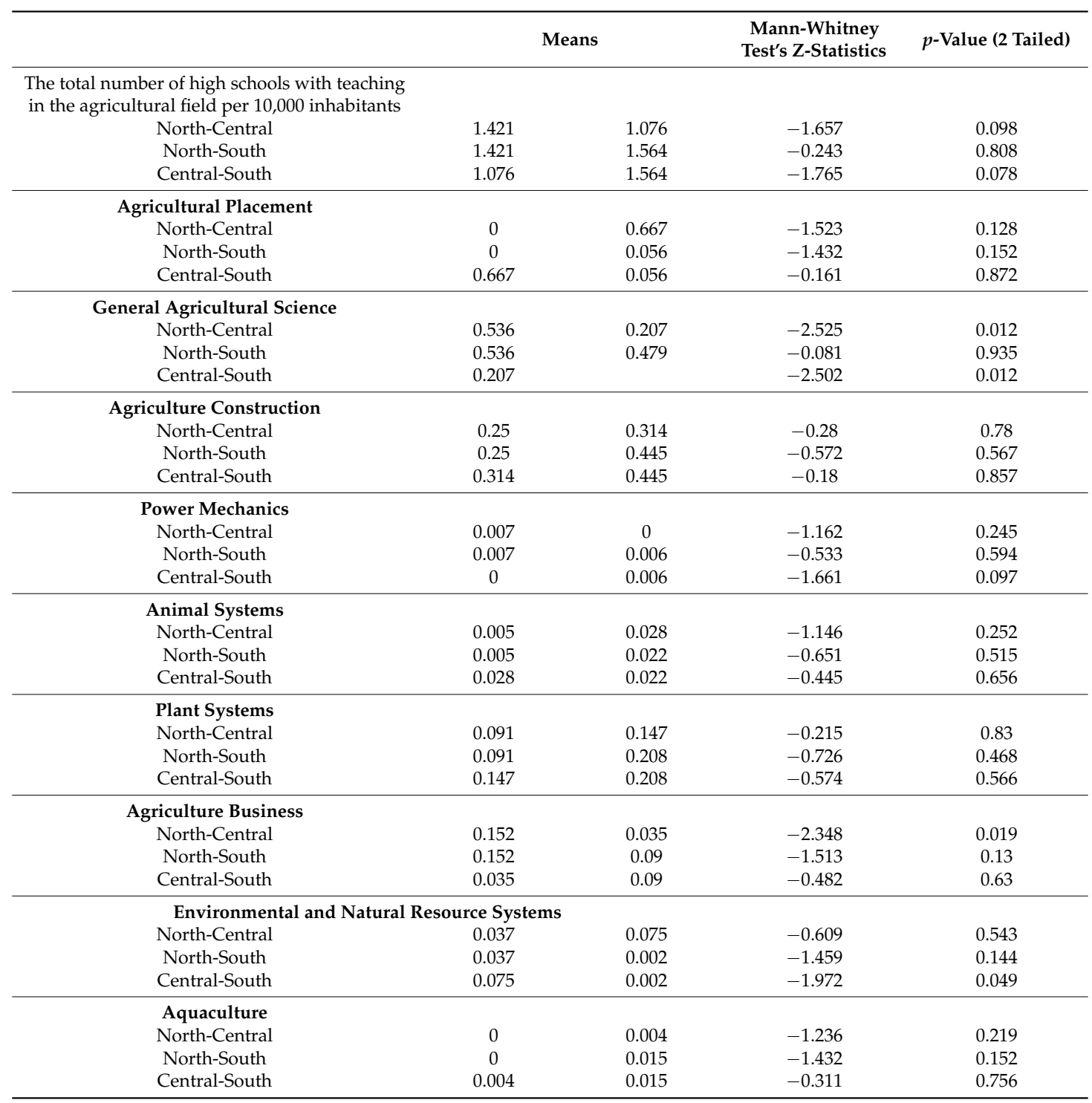


The average number of high schools per 10,000 inhabitants with courses in Agricultural Science in counties in the Northern region (0.343) is higher compared to the Central region counties (0.199), with a $p$-value of $0.030<0.05$ on the Mann-Whitney test Z-statistics.

The average number of high schools per 10,000 inhabitants with General Agricultural Science studies in counties in the North (0.536) is higher compared to counties in the Central region (0.207).

The average number of high schools per 10,000 inhabitants with Agribusiness Systems courses in counties in the North (0.152) is higher compared with counties in the Central region (0.035).

\section{Conclusions}

The analysis of agriculture-related courses offered in Alabama's high schools reveals certain spatial differences. The first group of differences relate to Alabama's regions. The results of this analysis indicate that course offerings agricultural science, general agriculture-related science, and agricultural business systems are more concentrated in the Northern region compared to the Central region. No significant differences were found for pairwise comparisons of Central-South and South-North regions.

It was found that agriculture business system is more often offered in high schools in the North than in the Central and Southern regions. Plant Systems is studied in the South more often than in the North. Environmental and Natural Resources Systems is offered in more high schools in the Central region compared to the South.

The second group of differences is related to Alabama's Black Belt area. The results of this analysis indicate that the general agricultural science course is less concentrated in Alabama's Black Belt area compared to the rest of Alabama. Agriculture construction-related courses are offered more often in high schools located in Alabama's Black Belt area compared to high schools elsewhere in the State.

There are a few limitations to this analysis, however. The study has relied largely on the quantitative methodology of data collection and analysis. This method should be supplemented with qualitative methodology of data collection and analysis in future to provide a broader and more comprehensive perspective on the overall impact and effectiveness of the teaching of agricultural-related courses in Alabama's high schools. For instance, in the future research design could employ case study methodology or content analysis to provide a holistic picture of the given subject.

Author Contributions: R.J. was primarily responsible for data collection and analysis in addition to the development of initial draft manuscript. C.C. was primarily responsible for development of research concept and methodology. Additionally, he reviewed and edited draft document and contributed to the response to reviewer's concerns.

Funding: No external funding was secured for this study.

Conflicts of Interest: The authors declare no conflict of interests.

\section{References}

Agclassroom.org. 2017. Excellence in Teaching Award 2017. Available online: https://www.agclassroom.org/ teacher_award/17.cfm (accessed on 3 November 2017).

Aitbayevaa, Gul'zamira D., Mariyash K. Zhubanovaa, Tulebike A. Kulgildinovaa, Gulsum M. Tusupbekovaa, and Gulnar I. Uaisova. 2016. Formation of Education Clusters as a Way to Improve Education. International Journal of Environmental \& Science Education 9: 3053-64. [CrossRef]

Alabama Department of Agriculture \& Industries. 2015. Strategic Plan to Grow Alabama's. Montgomery: Alabama Department of Agriculture \& Industries.

Alabama Department of Education. 2008. Alabama Course of Study Career and Technical Education. Available online: http:/ / www.alabamaffa.org/Teacher_Page_Documents / AFNR\%20Course\%20of\%20Study.pdf (accessed on 3 November 2017).

Alabama State Department of Education. 2017. Alabama State of Education Directory. Available online: http: / / web.alsde.edu/home/schoolinfo (accessed on 15 October 2017). 
Frenkel, Amnon, and Eran Leck. 2017. Spatial aspects of education-job matching in Israel. Regional Studies 51: 1063-76. [CrossRef]

Ilnicki, D. 2009. Main Spatial Aspects of the Functioning of Higher Education Institutions in Poland. European Spatial Research and Policy 16: 79-92. [CrossRef]

Ingram, Deborah D., and Sheila J. Franco. 2012. NCHS urban-rural classification scheme for counties. Vital and Health Statistics 2: 1-65.

Kim, Hae-Young. 2013. Statistical notes for clinical researchers: Assessing normal distribution using Skewness and kurtosis. Restorative Dentistry \& Endodontics 38: 52-54. [CrossRef]

Kim, Hae-Young. 2017. Statistical notes for clinical researchers: Chi-squared test and Fisher's exact test. Restorative Dentistry \& Endodontics 42: 152-55. [CrossRef]

Moore, Megan. 2016. Alabama Farmers Federation. Available online: http://alfafarmers.org/stories/ news-detail/young-farmers-dig-into-ag-education-at-shelby-county-school\#.W2NPCNIzq9K (accessed on 14 December 2016).

Purdue. 2015. United States Department of Agriculture. Available online: https://www.purdue.edu/usda/ employment/ (accessed on 2 November 2017).

U.S. Geological Survey, National Geospatial Technical Operations Center. 2018. USGS National Boundary Dataset (NBD) for Alabama 20180614 State or Territory Shapefile: U.S. Geological Survey. Denver: NGTOC, Available online: https:/ / www.sciencebase.gov/catalog/item/59fa9f59e4b0531197affb0f (accessed on 3 November 2017).

Veeravalli, Devanathan Sevilimedu. 2010. Higher Education and Cluster College Concepts-Indian Views. SSRN Electronic Journal. [CrossRef]

Wang, Hui-Chen. 2010. Institutions of Higher Education and the Regional Economy: A Long-Term Spatial Analysis. Economics Research International 2010: 1-19. [CrossRef]

Zahn, Jennifer. 2012. Vincent High School Launches Urban Ag Program. Available online: http:/ /archive.jsonline. com/news/education/vincent-high-school-launches-urban-ag-program-jb79lgh-175174321.html/ (accessed on 2 November 2017).

(C) 2018 by the authors. Licensee MDPI, Basel, Switzerland. This article is an open access article distributed under the terms and conditions of the Creative Commons Attribution (CC BY) license (http:/ / creativecommons.org/licenses/by/4.0/). 